\title{
Chiasma redistribution in bivalents carrying supernumerary chromosome segments in grasshoppers
}

\author{
J. Navas-Castillo, \\ J. Cabrero and \\ J. P. M. Camacho
} Departamento de Genética, Facultad de Ciencias,
Universidad de Granada, 18071 Granada, Spain.

Four supernumerary chromosome segments showing different locations in the chromosomes and different C-banding reactions are studied in three grasshopper species in relation with chiasma distribution in the bivalents which carry them. The presence of any of these extra segments leads to a chiasma redistribution in the carrier bivalents, so that such a chiasma is formed preferentially in the furthest chromosome regions from the extra segment. This effect of the four supernumerary segments is independent of both their location on the chromosome and their C-banding reaction.

\section{INTRODUCTION}

Supernumerary chromosome segments of grasshoppers are heterogeneous in nature, as their response to $\mathrm{C}$-banding demonstrates, and this must be borne in mind when examining the effects they have on chiasma formation. In our previous investigations (Camacho et al., 1984) we found five types of extra segments, one being euchromatic and four heterochromatic. From the available data we inferred that only the non C-banded heterochromatic extra segments seemed to influence mean chiasma frequency. However, Riva et al. (1984) demonstrated an influence for a darkly C-banded supernumerary segment. However, the five types of extra segment did modify the chiasma distribution in the bivalents carrying them. Hitherto, only distally located segments and heterozygous individuals had been analysed. In this paper we extend our studies on chiasma distribution to four other supernumerary segments of three species including one segment proximally located in Oedipoda charpentieri and the analysis of homozygous segmented individuals in Chorthippus parallelus.

\section{MATERIALS AND METHODS}

Adult males studied in this paper belong to Calliptamus barbarus from La Alfaguara (Granada),
Chorthippus parallelus from Camino de Soportújar (Granada) and Oedipoda charpentieri from Alcalá la Real (Jaén) and Padul (Granada). Testes were fixed in $1: 3$ acetic alcohol. C-banding was made following the technique described in Camacho et al. (1984).

\section{RESULTS AND DISCUSSION}

In Calliptamus barbarus we have previously described an extra segment distally located in the $\mathrm{S}_{11}$ chromosome (Camacho and Cabrero, 1982). This segment is darkly C-banded only in its midzone and carries proximal and distal zones which do not C-band (see plates 15-19 in Camacho et al., 1984). In this paper we compare chiasma distribution in $S_{11}$ heteromorphic bivalents with that in unsegmented $S_{11}$ ones. For this purpose, we have distinguished three zones for chiasma localisation in this bivalent: proximal (P), interstitial (I) and distal (D), in relation with centromere position. In standard males $(\mathrm{BB})$ the $\mathrm{S}_{11}$ bivalent always forms a single chiasma, which was located proximally in 4.29 per cent, interstitially in 60 per cent and distally in 35.71 per cent of 70 diplotene cells analysed. In males heterozygous for the extra segment (BS), besides the terminal association between the segment and the telomere of the unsegmented $S_{11}$ which was observed in three cells, the 
unequal bivalent showed a single chiasma located proximally in 81.92 per cent, interstitially in 17.02 per cent and distally in 1.06 per cent of 94 diplotene cells analysed. Significant differences for chiasma distribution between both types of $S_{11}$ bivalents were demonstrated by a contingency $X^{2}$ test $\left(X_{(2)}^{2}=104 \cdot 21, \quad P<0 \cdot 001\right)$. Consequently, the heteromorphic $S_{11}$ bivalents (BS) show the chiasma proximally located in a significantly higher frequency than the basic ones (BB) (fig. 1).

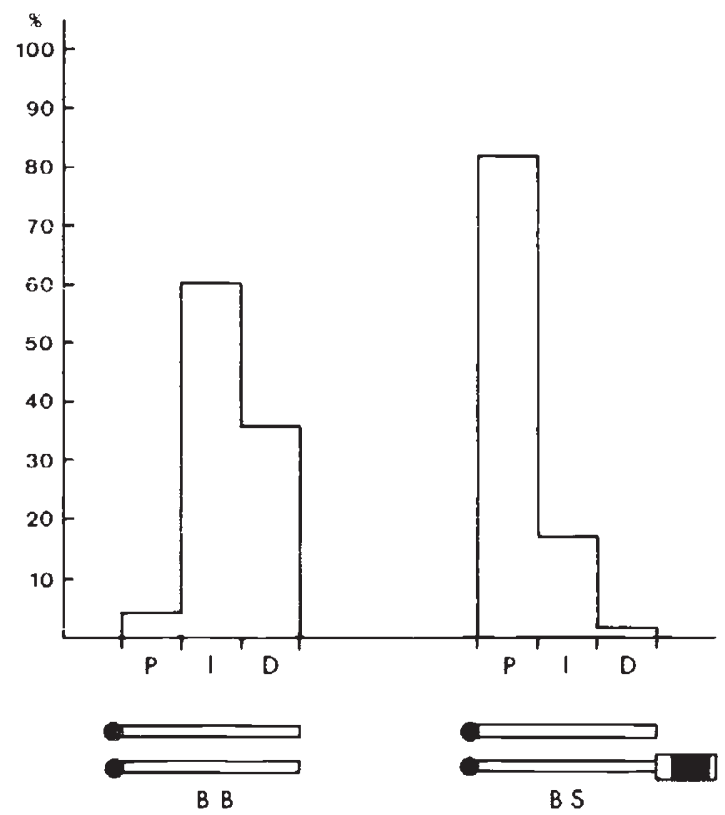

Figure 1 Effects of the heterochromatic and partly C-banded extra segment distally located in the $S_{11}$ chromosome of Calliptamus harharus on chiasma distribution in this bivalent, $\quad \mathrm{P}=$ proximal, $\mathrm{I}=$ interstitial and $\mathrm{D}=$ distal chiasma.

The supernumerary chromosome segments of Chorthippus parallelus have been studied extensively in British and French populations (John and Hewitt, 1966; 1969; Hewitt and John, 1968; 1970; Westerman, $1969 ; 1970)$. In Spanish populations we have found darkly C-banded extra segments in the $\mathbf{M}_{5}, \mathbf{M}_{6}$ and $\mathbf{M}_{7}$ chromosomes, and a non C-banded one in the $\mathrm{S}_{8}$ chromosome (Camacho et al., 1984). In the present investigation we study chiasma distribution in the three classes (BB, BS and $\mathrm{SS}$ ) of $\mathrm{M}_{7}$ and $\mathrm{S}_{8}$ bivalents. The high frequency of these extra segments in the population analysed $\left(q_{\mathrm{M}_{7}}=0.734, q_{\mathrm{S}_{\mathrm{y}}}=0.359\right)$ allowed us to analyse segmented bivalents in both heterozygous and homozygous conditions. This gave us the possibility to investigate whether the chiasma redistribution is achieved by the structural heterozygosity or, on the contrary, by the physical presence of the extra heterochromatin. Furthermore, we could investigate this matter for two extra segments differing both by size and C-banding response. Table 1 summarises the results of our chiasma scores in $\mathbf{M}_{7}$ bivalents. The two extra segments in the $M_{7}$ chromosomes appeared terminally associated with one another in nine SS bivalents, and with the $\mathrm{M}_{7}$ telomere in three BS bivalents. These cells have not been included in the statistical comparisons. Table 2 shows contingency $X^{2}$ tests between chiasma distribution in the three types of $M_{7}$ bivalents. While the heteromorphic $M_{7}$ bivalents (BS) do not show a significantly different chiasma distribution pattern with respect to the basic ones (BB), the homozygous SS bivalents show significant differences with both BB and BS bivalents.

The results of our chiasma scores in the $S_{8}$ bivalents are shown in table 3. Terminal associations between two of these segments in homozygous SS bivalents or between the segment and the telomere of the unsegmented $\mathrm{S}_{8}$ in $\mathrm{BS}$ bivalents were not observed. Table 4 summarises a series of contingency $X^{2}$ tests comparing the different locations of the single chiasma in the three classes of $\mathrm{S}_{8}$ bivalents. The BS bivalents show a significantly different pattern of chiasma distribution with respect to the $\mathrm{BB}$ ones. The difference rests on a greater frequency of proximal and interstitial chiasmata and a lower frequency of distal chiasmata. On the other hand, chiasma distribution does not differ significantly between BS and SS

Table 1 Chiasma distribution in three different types of $\mathrm{M}_{7}$ bivalent of Chorthippus parallelus. Three zones have been distinguished for chiasma formation: proximal (P), interstitial (I) and distal (D). $\mathrm{S}=$ extra segment associations

\begin{tabular}{lrlrlr}
\hline $\begin{array}{l}\text { Type of } \mathrm{M}_{7} \\
\text { bivaient }\end{array}$ & $\mathrm{P}$ & $\mathrm{I}$ & $\mathrm{D}$ & $\mathrm{S}$ & Total \\
\hline BB & $5(12 \cdot 20 \%)$ & $27(65 \cdot 85 \%)$ & $9(21 \cdot 95 \%)$ & - & 41 \\
BS & $11(21 \cdot 57 \%)$ & $36(70 \cdot 59 \%)$ & $4(7.84 \%)$ & 3 & $51(+3)$ \\
SS & $41(38 \cdot 68 \%)$ & $52(49 \cdot 06 \%)$ & $13(12 \cdot 26 \%)$ & 9 & $106(+9)$ \\
\hline
\end{tabular}


Table 2 A series of $X^{2}$ tests comparing chiasma distribution patterns between the three types of $M_{7}$ bivalent of Chorthippus parallelus

\begin{tabular}{|c|c|c|c|}
\hline $\begin{array}{l}\text { Types of } \mathrm{M}_{7} \\
\text { bivalent } \\
\text { compared }\end{array}$ & $\mathrm{df}$ & $X^{2}$ & $\mathbf{P}$ \\
\hline $\mathrm{BB} / \mathrm{BS} / \mathrm{SS}$ & 4 & $15 \cdot 31$ & $0.01-0.001$ \\
\hline $\mathrm{BB} / \mathrm{BS}$ & 2 & $4 \cdot 43$ & $>0.05$ \\
\hline $\mathrm{BS} / \mathrm{SS}$ & 2 & $6 \cdot 51$ & $0.05-0.01$ \\
\hline $\mathrm{BB} / \mathrm{SS}$ & 2 & $10 \cdot 03$ & $0.01-0.001$ \\
\hline
\end{tabular}

Table 3 Chiasma distribution in three different types of $\mathrm{S}_{8}$ bivalent of Chorthippus parallelus. Three zones have been distinguished for chiasma formation: proximal (P), interstitial (I) and distal (D)

\begin{tabular}{lllll}
\hline $\begin{array}{l}\text { Type of } \mathrm{S}_{8} \\
\text { bivalent }\end{array}$ & $\mathrm{P}$ & $\mathrm{l}$ & $\mathrm{D}$ & Total \\
\hline BB & $2(3 \cdot 33 \%)$ & $22(36 \cdot 67 \%)$ & $36(60 \%)$ & 60 \\
BS & $24(40 \%)$ & $33(55 \%)$ & $3(5 \%)$ & 60 \\
SS & $12(40 \%)$ & $18(60 \%)$ & - & 30 \\
\hline
\end{tabular}

Table 4 A series of $X^{2}$ tests comparing chiasma distribution patterns between the three types of $\mathrm{S}_{8}$ bivalent of Chorthippus parallelus

\begin{tabular}{llll}
\hline $\begin{array}{l}\text { Types of } \mathrm{S}_{8} \\
\text { bivalent } \\
\text { compared }\end{array}$ & df & $\boldsymbol{X}^{2}$ & \multicolumn{1}{c}{$\mathrm{P}$} \\
\hline $\mathrm{BB} / \mathrm{BS} / \mathrm{SS}$ & 3 & 66.82 & $<0.001$ \\
$\mathrm{BB} / \mathrm{BS}$ & 2 & 48.74 & $<0.001$ \\
$\mathrm{BS} / \mathrm{SS}$ & 1 & 1.59 & $>0.05$ \\
$\mathrm{BB} / \mathrm{SS}$ & 1 & 37.72 & $<0.001$ \\
\hline
\end{tabular}

bivalents, which indicates that, in this case, the effect on chiasma location is due to the presence of the segment(s) and not to structural heterozygosity.

The effect of the extra segments on chiasma distribution in the $S_{8}$ bivalent is more pronounced than that in the $M_{7}$. This presumably is not due to the different $\mathrm{C}$-banding reactions of both segments, because the extra segments in other grasshopper species, which C-band darkly like that in the $\mathrm{M}_{7}$ of Ch. parallelus, have drastic effects on chiasma distribution (see Camacho et al., 1984). We think that the difference in the intensity of this chiasma effect might be due to the greater size of the $S_{8}$ extra segment. The possible relation between the size of supernumerary chromosome segments and chiasma formation will be investigated in future works.

The fourth type of supernumerary segment analysed in this paper is proximally located in the $S_{11}$ chromosome of Oedipoda charpentieri. This extra segment C-bands darkly (Navas-Castillo et al., in preparation). The $S_{11}$ bivalents always form a single chiasma which, in basic BB bivalents we found proximally located in 20 per cent, interstitially in 33 per cent and distally in 46 per cent of 69 diplotene cells. However, in the 22 diplotene cells analysed from heterozygous males, the $S_{11}$ BS bivalent always showed the chiasma distally located (fig. 2).

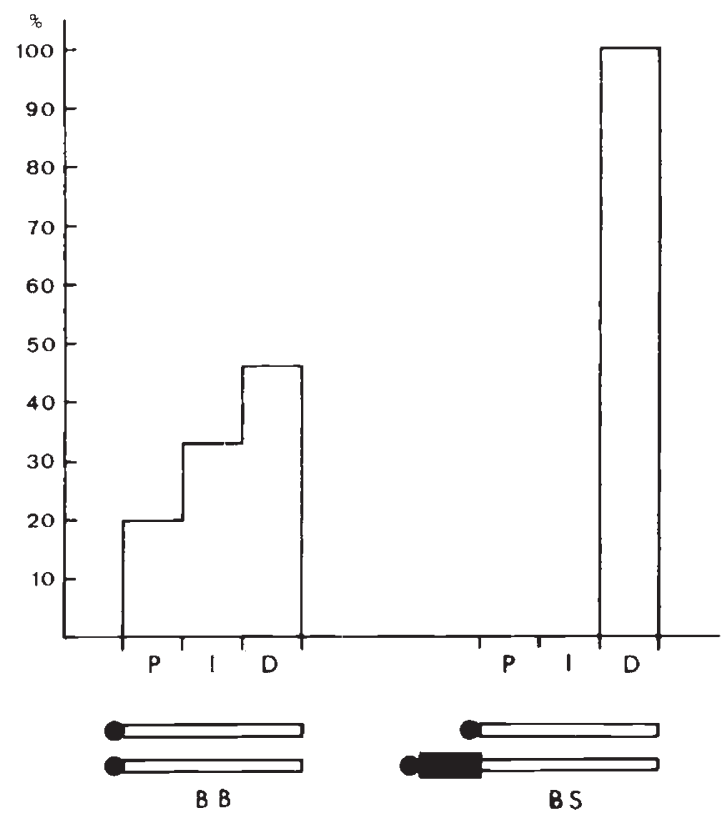

Figure 2 Effects of the heterochromatic and darkly C-banded extra segment proximally located in the $S_{11}$ chromosome of Oedipoda charpentieri on chiasma distribution in this bivalent. $\mathrm{P}=$ proximal, $\mathrm{I}=$ interstitial and $\mathrm{D}=$ distal chiasma.

In conclusion, the supernumerary chromosome segments of grasshoppers may be considered as partial crossover suppressors because their presence produces a chiasma redistribution in the bivalent carrying them, so that the chromosome regions furthest from the extra segment are preferred for chiasma formation. This effect is independent of the eu- heterochromatic nature of the extra segment (Camacho et al., 1984), the response to C-banding and the location of the extra segment in the chromosome. However, the intensity of the effect may depend on the size of the segment. Anyway, this effect could play a role in both the achievement of coadapted genic complexes or supergenes in chromosome regions near to supernumerary segments (Fox et al., 1973; García- 
Lafuente et al., 1983) and the disruption of internally coadapted chromosome regions in which chiasmata are more frequent in presence of supernumerary segments. The second effect would be parallel to that suggested by Shaw et al. (1982) for pericentric inversions in Caledia captiva.

\section{REFERENCES}

CAMACHO. I. P. M. ANI) ( ABRI:RO, J. 1982. Supernumary seg ments in five species of grasshoppers (Orthoptera: Acridoidea). Genetica, 59, 113-117.

CAMACHO, J. P. M., VISIERAS, I, NAVAS, J, ANI) (ABRERO, J. 1984. (-heterochromatin content of supernumerary chromosome segments of grasshoppcrs: detection of an euchromatic extra segment. Heredity, 53, 167-175.

FOX, D. P., ('ARTIR, K. ('. ANI) HI:WITI, C. M, 1973. Giemsa banding and chiasma distribution in the desert locust. Heredity, 31, 272-276.

(IARCIA-LAFUI:NTE, R., LOPEZ-FERNANDEZ, C. AND GOSAI. VEZ. J. 1983. Extra heterochromatin in natural populations of Gomphocerus sibiricus (Orthoptera: Acrididae) 2. Chiasma distribution in the $\mathbf{M}_{7}$ bivalent. Cytohios, 37 , $149-155$
HI:WITY, (i. M. ANI) IOHN, B. 1968. Parallel polymorphism for supernumerary segments in Chorthippus parallelus (Zetterstedt) I. British populations. Chromosoma, 25, 319-342.

H1:WITT, (i. M. ANI) JOHN, B. 1970. Parallel polymorphism for supernumerary segments in Chorthippus parallelus (Zetterstedt) IV. Ashurst re-visited. Chromosoma, 31, 198-206.

JOHN, B. AND HEWITT, G. M. 1966. A polymorphism for heterochromatic supernumerary segments in Chorthippus parallelus. Chromosoma, 18, 254-271.

JOHN, B. AND HIWITT, G. M. 1969. Parallel polymorphism for supernumerary segments in Chorthippus parallelus (Zetterstedt) III. The Ashurst population. Chromosoma, 28, 73-84.

RIVA, F., FOX, I). P., GIRALDEZ, R. ANI) SANTOS, J. L. 1984. Chiasma frequency and distribution in the presence and absence of supernumerary chromosome segments in the grasshopper, Euchorthippus pulvinatus gallicus. Heredity, $53,101-106$.

SHAW, D. D., WILKINSON, P. AND COATES, D. J. 1982. The chromosomal component of reproductive isolation in the grasshopper Caledia captiva II. The relative viabilities of recombinant and non-recomhinant chromosomes during embryogenesis. Chromosoma, 86, 533-549.

WISIIIRMAN, M. 1969. Parallel polymorphism for supernumerary segments in Chorthippus parallelus (Zetterstedt) 11. French populations. Chromosoma, 26, 7-21.

WESTERMAN, M. 1970. Parallel polymorphism for supernumerary segments in Chorthippus parallelus V. A new polymorphism in Europe. Heredity, 25, 662-667. 